\title{
Biopsy of Thyroid Gland
}

National Cancer Institute

\section{Source}

National Cancer Institute. Biopsy of Thyroid Gland. NCI Thesaurus. Code C51613.

Removal of tissue from the thyroid gland for microscopic examination. 